\title{
DETECTION AND REDUCTION OF LAND DEGRADATION IN SMARDE MUNICIPALITY RURAL TERRITORY
}

\author{
Vita Cintina, Vivita Baumane \\ Latvia University of Agriculture \\ vita.cintina@1lu.lv; vivita.baumane@1lu.lv
}

\begin{abstract}
The aim of the paper is to explore the possibilities of detection and reduction of land degradation in Smarde municipality rural territory $\left(56^{\circ} 57^{\prime} 18^{\prime \prime} \mathrm{N} ; 23^{\circ} 20^{\prime} 17^{\prime \prime} \mathrm{E}\right)$. To carry out land degradation prevention measures, initially the territories of degraded land should be determined. This paper highlights the field inspection method. For territory inspection a model was used that gave the opportunity to identify degradation types with their characteristic features and possibilities to reduce the land degradation. The territory of Smarde municipality rural territory was inspected in nature and degraded territories identified. The costs of land degradation elimination depend on the type of land degradation. In territories where the land degradation reduction or elimination has been done, its control has to continue in order to stop the development of land degradation.
\end{abstract}

Key words: land degradation, field inspection, real estate.

\section{Introduction}

There are several land use and protection issues that in the existing legislation are not sufficiently regulated, but regulation is necessary to ensure the sustainable use of land, for example, land-use principles and state and local government role in the land management. Currently, laws and regulations are rather fragmented, or there does not exist an adequately defined framework for land degradation.

Experience of other countries shows that a country with a small territory or for economics usable land area (Denmark, Finland, Switzerland, Austria) rather strictly regulates land use and protection issues. (Austrian Spatial..., 2011; Finland's National..., 2002; Mugli, 2014; Spatial planning..., 2007) Up to now in Latvia the land degradation prevention issues in development planning documents, laws and regulations have been mentioned only briefly. In the National Development Plan from 2007 to 2013 (Nacionālās attīstības plāns, 2006) (approved by the Cabinet of Ministers on 4 July 2006, regulation No. 564), the country's growth prerequisites and tasks are defined. In the section "Reasonable use and preservation of natural environment" of the National Development Plan as challenges are defined - promotion of biodiversity and conservation of protected areas, as well as promotion of degraded territory remediation and revitalization.

In the European Commission's agenda and documents only in recent years there have appeared issues of land degradation. The European Commission on 22 September 2006 approved the guidelines of thematic strategy of soil protection and developed the draft of directive on soil protection 'Directive, which establishes a framework for the protection of soil and amending Directive 2004/35/EC' (Zemes politikas ...., 2008). In these documents it is stressed that soil degradation is a serious problem across
Europe, and studies show that the degradation rates could further increase. The soil can be considered essentially a non-renewable resource. Any damage to the soil structure also damages other environmental elements and ecosystems. Soil biodiversity assessment and biological monitoring is required to correctly assess soil degradation and correlated risks, as well as soil quality (Aksoy et al., 2017; Squire et al., 2015).

In recent years, increasing attention is being paid to sustainable land use issues (Fischer, Klauer, \& Schiller, 2013; Pašakarnis, Morley, \& Malienè, 2013; Sklenicka, 2016). Not only in the world (Kosmas et al., 2016; Price et al., 2015; Smiraglia et al., 2016; Turner et al., 2016), but also in Latvia the land degradation processes are taking place. The cause of land degradation could be the formation of bushes on agricultural land, coastal erosion, lack of maintenance of drainage systems and land bogging, pollution, landslides, abandonment of built-up areas and the soil degradation. On the other hand, types of soil degradation are: soil erosion, soil compaction, decline of organic matter in the soil, loss of soil biodiversity, decrease of soil $\mathrm{pH}$ level, and soil pollution (Lapina \& Baumane, 2015).

It is important to determine the land degradation and to take measures to prevent it. To carry out land degradation prevention measures, initially the territories of degraded land should be determined. These territories can be identified differently, for example, performing field works like field inspection or performing data analysis. This paper highlights the field inspection method.

The aim of the paper is to explore the possibilities of detection and reduction of land degradation in Smarde municipality rural territory. To achieve the aim, the following tasks were set:

- to analyse land degradation types in Smarde municipality rural territory; 
- to carry out field inspection;

- to identify the approximate costs of the land degradation prevention.

\section{Materials and Methods}

The research territory which was inspected is located in Northwest side of Engure municipality and is located behind the Slokenbeka Manor (56 $58^{\prime} 39^{\prime \prime}$ $\mathrm{N} ; 23^{\circ} 13^{\prime} 34^{\prime \prime} \mathrm{E}$ ), about $7 \mathrm{~km}$ away from the Tukums city center, and is bordering with Smarde municipality rural territory borders and is located next to the Tukums airfield. Approximate area of inspected territory is 3000 ha.

For territory inspection a theoretical model was used that gave the opportunity to identify degradation types with their characteristic features and possibilities to reduce the land degradation. In Smarde municipality rural territory 7 types of degradation were observed: agricultural land overgrowing with bushes, land bogging, land pollution, excessive cutting of forests, abandonment of buildings and land, coastal erosion and soil degradation. For all of these degradation types a theoretical model of solutions of how to prevent degradation was developed.

The theoretical model for reduction of land degradation:

\section{Agricultural land overgrowing with bushes}

To effectively prevent this type of land degradation and prevent the loss of valuable agricultural land territories, it is necessary to:

- Make effective use of agricultural land;

- Clear the territories which are overgrown with bushes;

- Reforest territory where the scrubland amount reached significant areas and height;

- Perform deforestation on a regular basis and make regular follow up of risk areas;

- Control the territories of agricultural land which are located in the immediate vicinity of forest areas;

- Introduce sanctions against individuals who have maliciously or inadvertently contributed to the land overgrowth with bushes.

\section{Land bogging}

The necessary measures to stop the land bogging up process and prevent the loss of valuable land that would be used for economic activities and gain of benefits from them are:

- Afforestation;

- More efficient use of land;

- Prevent deforestation where this would contribute to land bogging up process;

- Drainage system installation;
- Elaboration of drainage systems if they are installed, but do not work;

- Introduction of sanctions against individuals who have maliciously or inadvertently contributed to the land booging up process.

\section{Land pollution}

Pollution is one of those things, without which in today's overpopulated world it is not possible to exist and there will always be territories that are contaminated, however, there should be some specially designated areas, intended for pollution and contamination which should be controlled and limited. Pollution may arise from abandoned buildings, industrial buildings, improper economic activities and improper use of agricultural chemicals. To prevent pollution it is necessary to:

- Terminate pollution;

- If the pollution is already formed and there is no possibility to terminate it, it should be controlled to discourage the expansion of pollution;

- Use properly the agricultural chemicals;

- Destruct the buildings and their polluting elements, or recycle them effectively;

- Introduce sanctions against individuals who have maliciously or inadvertently contributed to the land pollution.

\section{Excessive cutting of forests}

The necessary measures to prevent this type of land degradation effectively and to prevent the formation of bogged up territories are:

- Deforestation control;

- Deforestation only at designated places;

- Eradication of illegal felling area formation;

- Afforestation;

- Introduction of sanctions against individuals who have maliciously or inadvertently contributed to excessive cutting of forests.

\section{Abandonment of buildings and land}

Buildings and land abandonment is one of the basic factors that causes land degradation formation because if the land and building on it is effectively used for business purposes or just being cultivated, there does not form polluted soil, huge industrial building slums and territories that are overgrown with bushes. The necessary measures to prevent this type of land degradation effectively are:

- Demolition of buildings and the use of land for other purposes;

- Restoration of buildings and their effective reuse; 
- Introduction of sanctions against abandoned land and building owners;

- Introduction of sanctions against individuals who have maliciously or inadvertently contributed to abandonment of buildings and land.

\section{Coastal erosion}

Latvia is bordering with the Baltic Sea, therefore it is typical in this country to have coastal erosion, which is one of the types of land degradation. Coastal erosion does not occur merely at sea coast, but also in rivers and lakes, which have frequent changes in water level and, of course, annual flooding, and less frequently ongoing floods. The necessary measures to prevent coastal erosion are:

- Strengthening of sea coastal in risk areas;

- Water level control of rivers and lakes;

- Strengthening of river and lake coasts in risk areas;

- Establishment of drainage systems in risk areas;

- Introduction of sanctions against individuals who have maliciously or inadvertently contributed to costal erosion.

\section{Soil degradation}

Formation of soil degradation is promoted by incorrect farming, lack of drainage systems and other factors. The necessary measures to prevent this type of degradation are:

- Efficient and proper farming;

- Regular land treatment and cultivation;

- Soil elaboration;

- Installation or improvement of drainage systems;

- Introduction of sanctions against individuals who have maliciously or inadvertently contributed to soil degradation.

These land degradation solutions for the seven causes of land degradation are the ones that would put an end, control or prevent land degradation from occurring, except for a solution to impose sanctions, which is the ultimate tool when the land degradation process has already occurred and the guilty party has to be punished.

If the landowner does not eliminate the consequences of land degradation himself, but invite such service provider, then separately for each unit of land there are costs offered for the land degradation prevention, as well as prices available currently on the market for such services. Land degradation costs are summarized by the competitive dialogue between the providers that offer this kind of services.

In nature we inspected the territory of Smarde municipality rural territory and identified 25 degraded territories. This paper highlights five of these territories.

\section{Results and Discussion}

The first territory is named Jumji, with cadastral designation 90820040178 and total area of 3.89 ha from which 0.95 ha is degraded. Type of land degradation is agricultural land overgrown with bushes. This degraded territory would require clean up from the bushes for successful use of agricultural land. Scrub cutting for 0.95 ha territory, if the sawn timber is retained, would cost $200-250$ euros, according to the price survey; if the sawn timber is not retained but returned to the service provider, it would serve as a service fee and then the costs for the owner are minimal or hardly any. Figure 1 shows the real estate Jumji, in which the degraded territory is hatched.

The second territory is named Kursedvare, with cadastral designation 90820120057 and total area of 7.33 ha from which 3.53 ha is degraded. Types of land degradation are agricultural land overgrown with bushes and insufficient drainage system maintenance that have led to land bogging. This degraded territory would require clean up from the bushes and drainage system cleaning in order to successfully use the agricultural land. Scrub cutting for 3.51 ha territory

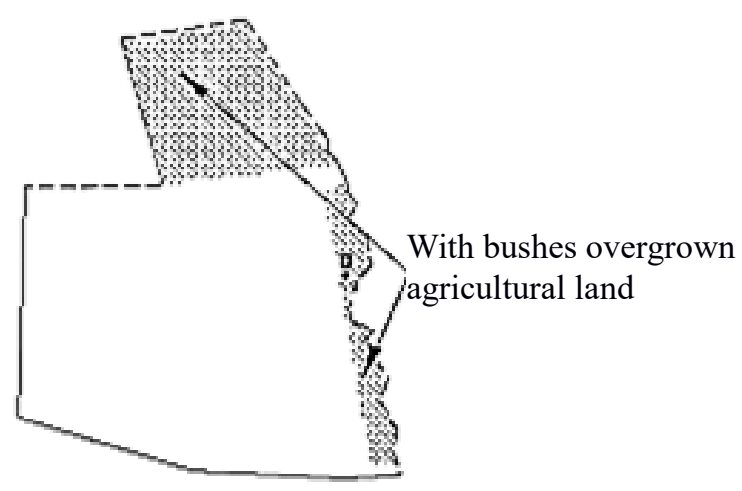

Figure 1. Agricultural land overgrown with bushes in the real estate Jumji. 


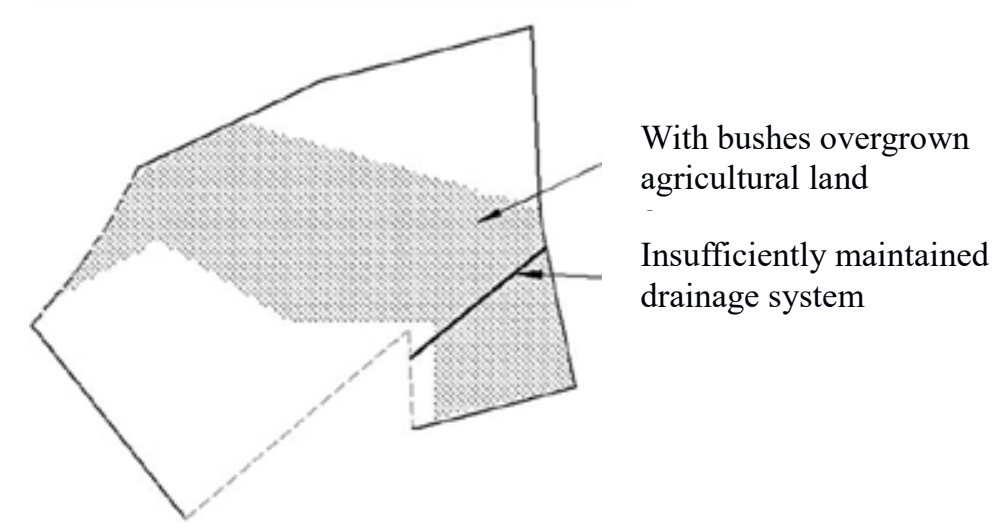

Figure 2. Agricultural land overgrown with bushes and insufficiently maintained drainage system in the real estate Kursedvare.

and drainage system cleaning for 0.02 ha territory would cost $200-250$ euros according to the price survey, but if the sawn timber is returned to the service provider, then it would serve as a service fee and then the costs for the owner are minimal or hardly any. Figure 2 shows the real estate Kursedvare, in which the territory overgrown with bushes is hatched and the insufficiently maintained drainage system is highlighted.

The third territory is named Zemnieki, with cadastral designation 90820040126 and total area of 2.62 ha from which 0.05 ha is degraded. Type of land degradation is abandonment of buildings. This degraded territory would require clean up from

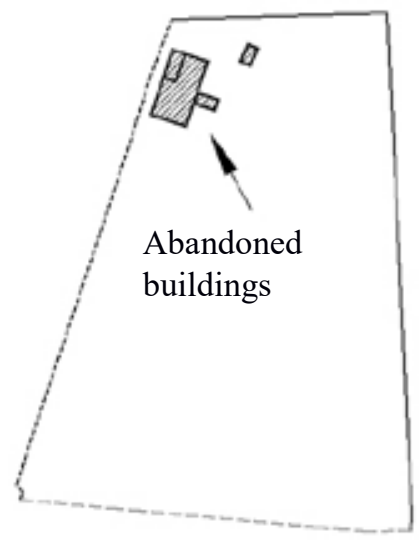

Figure 3. Abandoned buildings in the real estate Zemnieki.

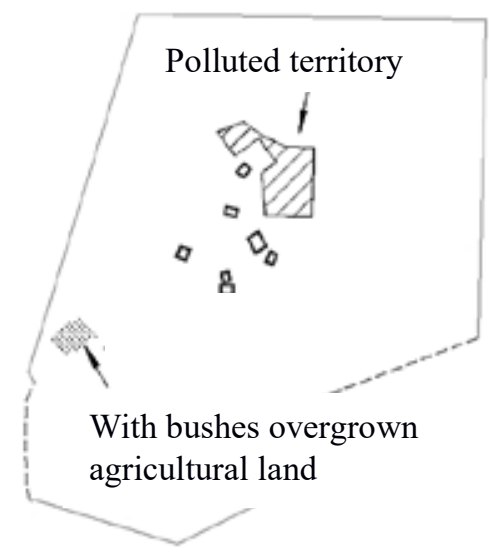

Figure 4. Agricultural land overgrown with bushes and polluted territory in the real estate Pauri. 


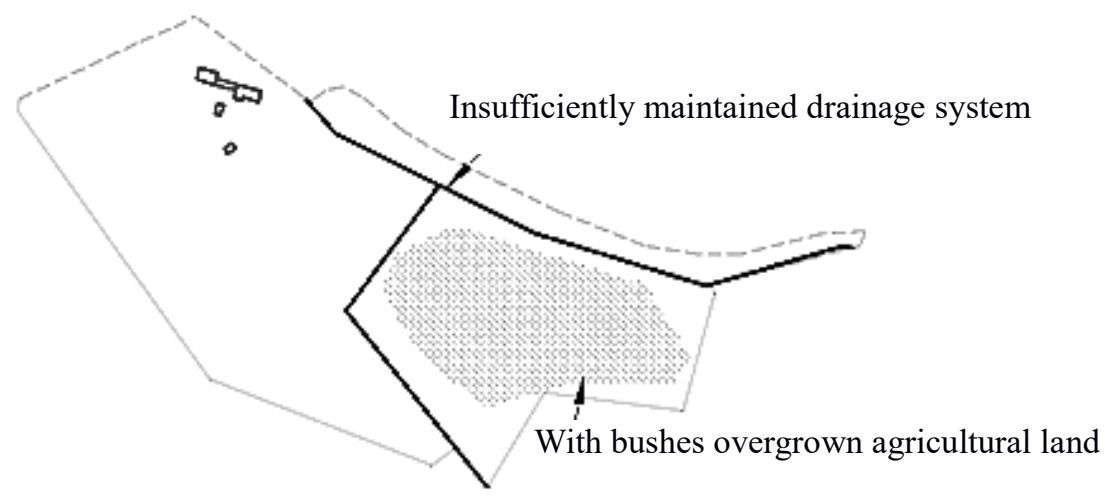

Figure 5. Agricultural land overgrown with bushes and insufficiently maintained drainage system in the real estate Eglites.

debris. Debris removal for this territory would cost approximately 10000 euro. Figure 3 shows the real estate Zemnieki.

The fourth territory is named Pauri, with cadastral designation 90820090026 and total area of 10.03 ha from which 0.27 ha is degraded. Types of land degradation are agricultural land overgrown with bushes (in this territory it is $0.04 \mathrm{ha}$ ) and land pollution (in this territory $-0.23 \mathrm{ha}$ ). This degraded territory would require clean up from the bushes for successful use of agricultural land. Scrub cutting for 0.04 ha territory, if the sawn timber is retained, according to the price survey, would cost up to 50 euros and the polluted territory clean up would cost from $5000-$ 5500 euro. Figure 4 shows the real estate Pauri.

The fifth territory is named Eglites, with cadastral designation 90820040071 and total area of 6.48 ha from which 1.67 ha is degraded. Types of land degradation are agricultural land overgrown with bushes (in this territory it is $1.55 \mathrm{ha}$ ) and insufficient drainage system maintenance - ditch overgrown with bushes (in this territory $-0.12 \mathrm{ha}$ ). This degraded territory would require clean up from the bushes and drainage system cleaning for successful use of agricultural land. Scrub cutting for 1.55 ha territory and drainage system cleaning for 0.12 ha territory according to the price survey would cost $430-450$ euros, but if the sawn timber is returned to the service provider so that it would serve as a service fee, then the cost for owner is minimal or hardly any. Figure 5 shows the real estate Eglites, in which territory overgrown with bushes is hatched and the insufficiently maintained drainage system is highlighted.

During the territory inspection, the following degradation-promoting factors were identified:

- Scrub formation on agricultural land;

- Insufficient maintenance of drainage systems and land bogging;

- Abandonment of land, including the built-up area;
- Pollution (pesticides and fertilizers or chemicals).

As the most common problems were detected agricultural land overgrowing with bushes and lack of maintenance of drainage systems that have led to land bogging. These two types of degradation are easier to eliminate than pollution and abandonment of built-up area, and costs are significantly lower, too.

The costs of land degradation elimination were calculated per hectare for territories where scrub formation on agricultural land and lack of maintenance of drainage systems and land bogging were observed. Aaccording to the price survey, the average price of clean-up of one hectare which is overgrown with bushes is 250 euros.

Costs of land degradation elimination, in territories of built-up area abandonment and polluted territories, is estimated for $10 \mathrm{~m}^{3}$. Construction waste and debris removal costs for $10 \mathrm{~m}^{3}$ are 200 euros.

Pollution was detected in one unit of land. Pollutant is any substance that enters into the environment by human activities or natural processes, and which has harmful effects on living organisms. Environmental degradation means that the environment becomes unusable for its intended aims or if the living organisms and their community development are delayed. Environmental pollution and degradation can be caused by chemicals, physical agents or undesirable development of living organisms (biological factors) (Vides piesārņojums un.., [b.g].). Pollution removal would cost around $5000-5500$ euros.

\section{Conclusions}

1. Field inspection is one of the best ways to detect the land degradation.

2. Using the field inspection method, as the most common problems were detected agricultural land overgrowing with bushes and lack of maintenance of drainage systems that lead to land bogging. 
3. The costs of land degradation elimination are 250 euros per hectare, for territories where scrub formation on agricultural land and lack of maintenance of drainage systems and land bogging are observed, but costs for territories of built-up area abandonment and polluted territories are estimated to 200 euros per $10 \mathrm{~m}^{3}$.
4. In territories where the land degradation reduction or elimination has been done, the control has to continue in order to stop the development of land degradation, because not always it is possible to completely prevent land degradation, without repetitive prevention measures.

\section{References}

1. Aksoy, E., Louwagie, G., Gardi, C., Gregor, M., Schröder, C., \& Löhnertz, M. (2017). Assessing soil biodiversity potentials in Europe. Science of the Total Environment 589, pp. $236-249$.

2. Austrian Spatial Development Concept ÖREK 2011 (2011). Austrian Conference on Spatial Planning (ÖROK) resolution August 4th, 2011, Vienna. ISBN: 978-3-85186-102-0 Retrieved May 15, 2017, from: http://www.oerok.gv.at/fileadmin/Bilder/2.ReiterRaum_u._Region/1.OEREK/OEREK_2011/Dokumente _OEREK_2011/OEREK_2011_EN_Downloadversion.pdf.

3. Finland's National Land Use Guidelines (2002). Issued by the Council of State on November 30, 2000, Helsinki 2002. Retrieved May 15, 2017, from: https://helda.helsinki.fi/bitstream/handle/10138/135808/ Ymp\%C3\%A4rist\%C3\%B6opas_93en.pdf?sequence=1.

4. Fischer, B., Klauer, B., \& Schiller, J. (2013). Prospects for sustainable land-use policy in Germany: Experimenting with a sustainability heuristic. Ecological Economics Volume 95, November 2013, pp. $213-220$.

5. Kosmas, C., Karamesouti, M., Kounalaki, K., Detsis, V., Vassiliou, P., \& Salvati, L. (2016). Land degradation and long-term changes in agro-pastoral systems: An empirical analysis of ecological resilience in Asteroussia - Crete (Greece). CATENA Volume 147, December 2016, pp. 196 - 204.

6. Muggli, R. (2014, January). Spatial planning in Switzerland: a short introduction. Swiss Spatial Planning Association. Retrieved May 15, 2017, from: http:/www.vlp-aspan.ch/sites/default/files/at_en.pdf.

7. Nacionālais attīstības plāns 2007. - 2013. gadam (National Development Plan from 2007 to 2013) (2006). Apstiprināts ar MK 2006. gada 4. jūlija noteikumiem 'Noteikumi par Latvijas Nacionālo attīstības plānu 2007. - 2013. gadam'. LR Reǵionālās attīstības un pašvaldību lietu ministrija. Retrieved May 15, 2017, from: http://www.innovation.lv/wp-content/uploads/2013/10/Latvijas_Nacionalais_attistibas_ plans_2007-2013.pdf. (in Latvian).

8. Pašakarnis, G., Morley, D., \& Malienè, V. (2013). Rural development and challenges establishing sustainable land use in Eastern European countries. Land Use Policy 2013 vol: 30 (1) pp. 703 - 710.

9. Price, B., Kienast, F., Seidl, I., Ginzler, C., Verburg, P.H., \& Bolliger, J. (2015). Future landscapes of Switzerland: Risk areas for urbanisation and land abandonment. Applied Geography 57 (2015) pp. $32-41$.

10. Sklenicka, P. (2016). Classification of farmland ownership fragmentation as a cause of land degradation: A review on typology, consequences, and remedies. Land Use Policy 57 (2016) pp. $694-701$.

11. Smiraglia, D., Ceccarelli, T., Bajocco, S., Salvati, L., \& Perini, L. (2016). Linking trajectories of land change, land degradation processes and ecosystem services. Environmental Research 147 (2016) 590 600 .

12. Spatial planning in Denmark (2007). Ministry of the Environment, Denmark. Retrieved May 15, 2017, from: http://naturstyrelsen.dk/media/nst/attachments/planning_260907_ny6.pdf.

13. Squire, G., Hawes, C., Valentine, T., \& Young, M. (2015). Degradation rate of soil function varies with trajectory of agricultural intensification. Agriculture, Ecosystems \& Environment 2015 vol: 202 pp. 160 167.

14. Turner, K., Anderson, S., Gonzales-Chang, M., Costanza, R., Courville, S., Dalgaard, T., Dominati, E., Kubiszewski, I., Ogilvy, S., Porfirio, L., Ratna, N., Sandhu, H., Sutton, P., Svenning, J., Turner, G., Varennes, Y., Voinov, A., \& Wratten, S. (2016). A review of methods, data, and models to assess changes in the value of ecosystem services from land degradation and restoration. Ecological Modelling 2016 vol: 319 pp. $190-207$.

15. Vides piesārņojums un vides kvalitātes degradācija (Environmental pollution and environmental quality degradation) Retrieved February 15, 2017, from: http://profizgl.lu.lv/mod/book/view. php?id=19966\& chapterid=4454. (in Latvian).

16. Zemes politikas pamatnostādnes 2008. - 2014. gadam (Land Policy Guidelines from 2008 to 2014) (2008). Ministru kabineta 2008. gada 13. oktobra rīkojums Nr.613. Rīga Retrieved May 15, 2017, from: https:// 
www.zm.gov.lv/public/files/CMS_Static_Page_Doc/00/00/00/22/86/zemes_politikas_pamatnostadnes. pdf. (in Latvian).

17. Лапина, А.С., \& Баумане, В.3. (2015). Определение деградации земли в Латвии в муниципалитете Энгуре (Determination of land degradation in Latvia Engure municipality). Проблемы геологии $u$ освоения недр: труды $X I X$ Международного научного симпозиума имени академика M.А. Усова студентов $u$ молодых ученых, Томск, Россия, 6-10 апреля 2015 г. Министерство образования и науки РФ. Национальный исследовательский Томский политехнический университет. Томск, 2015. Том 1, C. 527 - 529. (in Russian). 